\title{
EVALUASI SISTEM PELAPORAN INSIDEN KESELAMATAN PASIEN DI RUMAH SAKIT
}

\author{
The Evaluation of Patient Safety Incident Reporting System at a Hospital \\ Arfella Dara Tristantia \\ IAKMI Jawa Tengah, Indonesia \\ E-mail:tristantia25@gmail.com
}

\begin{abstract}
Background: Incident reporting systems are designed to obtain information about patient safety and used for organizational and individual learning.

Aim: The objective is to evaluate the implementation of patient safety incident reporting system at a hospital of Surabaya.

Method: This study was an observational descriptive research supported by qualitative data. This study used Health Metrics Network (HMN) model.

Results: The results of the input evaluation show that there was a policy that regulates the incident report, but its implementation was still not appropriate with no direct funding. However, facilities were provided for reporting. There was socialization for employees who have different understanding and responsibility, organizational structure of the patient safety team, problem solving method which had not used PDSA (Plan, Do, Study, Action), and computerized technology.

Conclusion: The process evaluation shows that the indicators were in line with the rules. The data sources were in accordance with the guidelines. Data collection, process, presentation, and analysis were in line with the theory. The output evaluation shows the submission of incident reports had not been timely. Moreover, the report was complete and suitable to the existing guidelines, and it had been used for decision-making. It is required for the hospital to revise the guidebook of incidence reporting and improve the human resource skill.
\end{abstract}

Keywords: evaluation, incident, patient safety, reporting

\begin{abstract}
ABSTRAK
Latar Belakang: Sistem pelaporan insiden dirancang untuk memperoleh informasi tentang keselamatan pasien yang digunakan sebagai pembelajaran organisasi dan individu.

Tujuan: Tujuan penelitian adalah untuk mengevaluasi pelaksanaan sistem pelaporan insiden keselamatan pasien di rumah sakit. Penelitian berupa deskriptif observasional yang ditunjang dengan data kualitatif. Evaluasi dalam penelitian ini menggunakan model Health Metrics Network (HMN).

Hasil: Hasil evaluasi sistem pelaporan insiden keselamatan pasien di sebuah rumah sakit di Surabaya menunjukkan bahwa dari segi input telah ada kebijakan yang mengatur pelaporan insiden keselamatan pasien akan tetapi pada pelaksanaan kebijakan ini sayangnya masih belum sesuai, tidak ada dana yang secara langsung namun diberikan fasilitas untuk pembuatan laporan, para petugas telah diberikan sosialisasi namun adanya perbedaan pemahaman serta rasa tanggung jawab petugas, struktur organisasi tim keselamatan pasien telah ada, metode penyelesaian masalah belum menggunakan PDSA (Plan, Do, Study, Action), teknologi yang digunakan sudah terkomputerisasi.

Kesimpulan: Evaluasi segi proses, indikator sudah sesuai dengan peraturan, sumber data sudah sesuai dengan pedoman dan panduan insiden keselamatan pasien, serta pengumpulan, pengolahan, penyajian, dan analisis sudah sesuai dengan teori. Evaluasi segi output, penyerahan laporan insiden belum tepat waktu, laporan telah lengkap dan sesuai dengan panduan yang ada, dan laporan telah digunakan untuk pengambilan keputusan. Rumah sakit diharapkan dapat memperbaiki panduan pelaporan insiden dan meningkatkan kemampuan sumber daya manusia.
\end{abstract}

Kata Kunci: evaluasi,insiden, keselamatan pasien, pelaporan

Received: 13 December 2017

Published: 1 December

\section{PENDAHULUAN}

Pada Tahun 2007, World Health Organization menyatakan keselamatan pasien dijadikan prioritas dalam pelayanan kesehatan. Pemberi layanan kesehatan harus mengutamakan keamanan pasien 
sebagai prioritas. Undang-Undang RI No. 44 tahun 2009 tentang Rumah Sakit menjelaskan bahwa rumah sakit wajib menerapkan standar keselamatan pasien dan dilaksanakan melalui pelaporan insiden, menganalisis dan menerapkan pemecahan masalah dalam rangka menurunkan angka kejadian yang tidak diharapkan.

Kesalamatan pasien merupakan sebuah sistem yang membuat asuhan pasien lebih aman. Sistem tersebut terdiri dari asesmen risiko, identifikasi dan pengelolaan risiko pasien, pelaporan dan analisis insiden, kemampuan belajar dari insiden dan tindak lanjutnya, serta implementasi solusi untuk meminimalkan timbulnya risiko dan mencegah terjadinya cedera yang disebabkan oleh kesalahan akibat melakukan suatu tindakan atau tidak mengambil tindakan yang seharusnya diambil. Insiden keselamatan pasien merupakan setiap kejadian yang tidak disengaja dan kondisi yang mengakibatkan atau berpotensi mengakibatkan cedera yang dapat dicegah pada pasien (Kementerian Kesehatan RI, 2017).

Sistem pelaporan insiden didesain untuk memperoleh informasi tentang keselamatan pasien yang dapat digunakan bagi pembelajaran organisasi dan individu (Stavropoulou et al., 2015). Pelaporan insiden keselamatan pasien yang baik mampu mendukung upaya dalam melakukan identifikasi risiko pada insiden yang berpotensi menyebabkan ancaman keselamatan pasien (Gunawan et al., 2015). Pelaporan insiden keselamatan pasien merupakan suatu sistem untuk mendokumentasikan laporan insiden keselamatan pasien, analisis dan solusi untuk pembelajaran (Kementerian Kesehatan $\mathrm{RI}, 2017$ ).

Pelaporan insiden keselamatan pasien, menurut Komite Keselamatan Pasien Rumah Sakit (2015) dilakukan secara internal dan eksternal. Pelaporan internal yaitu adanya laporan tentang insiden yang terjadi di lingkungan rumah sakit. Pelaporan eksternal dilakukan dengan pelaporan dari rumah sakit ke Komite Keselamatan Pasien Rumah Sakit (KKP-RS) Nasional. Hasil dari pelaporan insiden keselamatan digunakan untuk pengambilan keputusan dan dijadikan sebagai pembelajaran. Pengambilan keputusan tersebut agar dapat tepat sasaran, maka diperlukan evaluasi pelaporan insiden keselamatan pasien.

Evaluasi pelaksanaan pelaporan dapat dilakukan evaluasi dengan menggunakan sebuah kerangka Health Metrics Network (HMN) yang dikembangkan oleh World Health Organization (WHO) pada tahun 2008. Kerangka Health Metrics Network (HMN) bukan hanya berfokus pada informasi tentang penyakit saja tetapi seluruh sistem statistik dan informasi kesehatan. Kerangka tersebut dijadikan standar secara universal untuk membimbing pengumpulan, pelaporan, dan penggunaan informasi kesehatan. Kerangka HMN bertujuan untuk mengembangkan dan memperkuat sistem informasi kesehatan negara serta membantu dalam penerapan monitoring dan evaluasi yang berkelanjutan (WHO, 2008). Selain itu, kerangka tersebut membantu mengidentifikasi kesenjangan dan isu penting yang dapat dilihat dari sudut pandang stakeholders yang terlibat dalam sistem informasi kesehatan (Mbondji et al., 2014).

Health Metrics Network mempunyai enam komponen utama yaitu sumber daya sistem informasi kesehatan, indikator kesehatan, sumber data, manajemen data, produk informasi, serta diseminasi dan penggunaan informasi kesehatan (Jakti, 2016). Salah satu dari informasi kesehatan negara adalah informasi tentang keselamatan pasien. Informasi tentang keselamatan pasien negara salah satunya didapatkan dari adanya sistem pelaporan eksternal atau pelaporan tentang insiden keselamatan pasien yang dikirim dari rumah sakit ke Komite Keselamatan Pasien Rumah Sakit Nasional.

Rumah sakit yang menjadi lokasi penelitian ini merupakan salah satu rumah sakit swasta yang telah menerapkan program keselamatan pasien dan telah memiliki sistem pelaporan insiden keselamatan pasien sejak tahun 2016. Menurut hasil wawancara dengan petugas Komite Peningkatan Mutu dan Keselamatan Pasien (PMKP), salah satu permasalahan yang ada yaitu sistem pelaporan yang belum berjalan optimal. Penelitian ini bertujuan untuk melakukan evaluasi pelaksanaan sistem pelaporan insiden keselamatan pasien yang ada di rumah sakit tersebut. Hasil dari penelitian ini dapat menjadi bahan masukan bagi pihak manajemen rumah sakit dalam meningkatkan penerapan sistem pelaporan insiden keselamatan pasien yang lebih baik lagi sehingga mampu mendukung program keselamatan pasien.

\section{METODE}

Penelitian ini merupakan studi deskriptif observasional dengan rancang bangun cross sectional yang ditunjang dengan data kualitatif. Informan dalam penelitian ini antara lain adalah Ketua Komite PMKP, Sekretaris Komite PMKP, Koordinator Keselamatan Pasien Rumah Sakit, Champion Mutu dan Keselamatan Pasien di unit yang sering melakukan laporan insiden keselamatan pasien.

Variabel dalam peneltian ini berdasarkan komponen model evaluasi Health Metrics Network (HMN) yang disesuaikan dengan kebutuhan peneliti terdiri dari segi input yakni kebijakan, pendanaan, sumber daya manusia, organisasi, metode penyelesaian masalah, teknologi. Indikator, sumber data, pengumpulan data, pengolahan data, penyajian data, analisis data dianalisis sebagai komponen proses. Ketepatan waktu, kelengkapan data, dan pengambil keputusan termasuk komponen output.

Pengumpulan data dengan melakukan wawancara kepada informan yang terlibat langsung terhadap sistem pelaporan insiden keselamatan pasien, melakukan observasi, dan telaah dokumen. Data sekunder didapatkan dari telaah dokumen laporan Insiden Keselamatan Pasien Triwulan II rumah sakit. Data yang telah dikumpulkan selanjutnya dianalisis dengan menggunakan model Miles dan Huberman yang terdiri dari tiga tahap yaitu reduksi data, penyajian data, dan verifikasi. Penyajian data yang digunakan dalam penelitian yaitu dengan teks yang bersifat naratif. Teknik 
pemeriksaan data menggunakan metode triangulasi sumber dan teori.

Keterbatasan penelitian ini yaitu hanya dilakukan selama satu bulan untuk melakukan evaluasi pelaksanaan sistem pelaporan insiden keselamatan pasien yang ada. Penelitian ini tidak bisa melihat umpan balik dari hasil evaluasi yang dilakukan oleh peneliti karena adanya keterbatasan waktu dan subjektivitas informan sangat tinggi.

\section{HASIL DAN PEMBAHASAN}

Informan penelitian ini terdiri dari informan utama yang memberikan informasi tentang pelaksanaan pelaporan insiden keselamatan pasien di rumah sakit dan informan penunjang sebagai sumber informasi untuk menguji kredibilitas hasil wawancara dengan informan utama. Informan utama terdiri dari tiga orang. Jabatan dari ketiga informan utama yaitu Ketua Komite PMKP, Koordinator Keselamtan Pasien, dan Champion Mutu dan Keselamatan pasien. Sedangkan informan penunjang yaitu sekretaris komite PMKP. Pendidikan terakhir dari seluruh informan adalah strata satu dengan pengalaman kerja lebih dari tiga tahun.

\section{Gambaran Umum Pembuatan Pelaporan Insiden Keselamatan Pasien di Rumah sakit}

Pelaporan insiden keselamatan pasien di Rumah sakit dilakukan ketika terjadi insiden. Alur pelaporan insiden keselamatan pasien terdiri dari dua jenis yaitu alur pelaporan insiden secara internal dan eksternal. Laporan insiden keselamatan pasien Sub-Komite Keselamatan Pasien Rumah Sakit merupakan suatu pelaporan yang tertulis setia pada Kejadian Tidak Diharapkan (KTD), Kejadian Tidak Cedera (KTC), Kondisi Potensial Cedera(KPC) atau Kejadian Nyaris Cedera (KNC) yang menimpa pasien atau kejadian lain yang menimpa keluarga dan pengunjung. Sedangkan laporan Insiden Keselamatan Pasien KKP-RS merupakan suatu pelaporan anonim dan tertulis ke KKP-RS setiap KTD atau KNC yang terjadi pada pasien yang kemudian dilakukan analisis penyebab, rekomendasi dan solusinya. Penjelasan alur pelaporan insiden keselamatan pasien secara internal dijelaskan melalui Gambar 1 tentang bagan alur pelaporan yang dimiliki oleh rumah sakit.

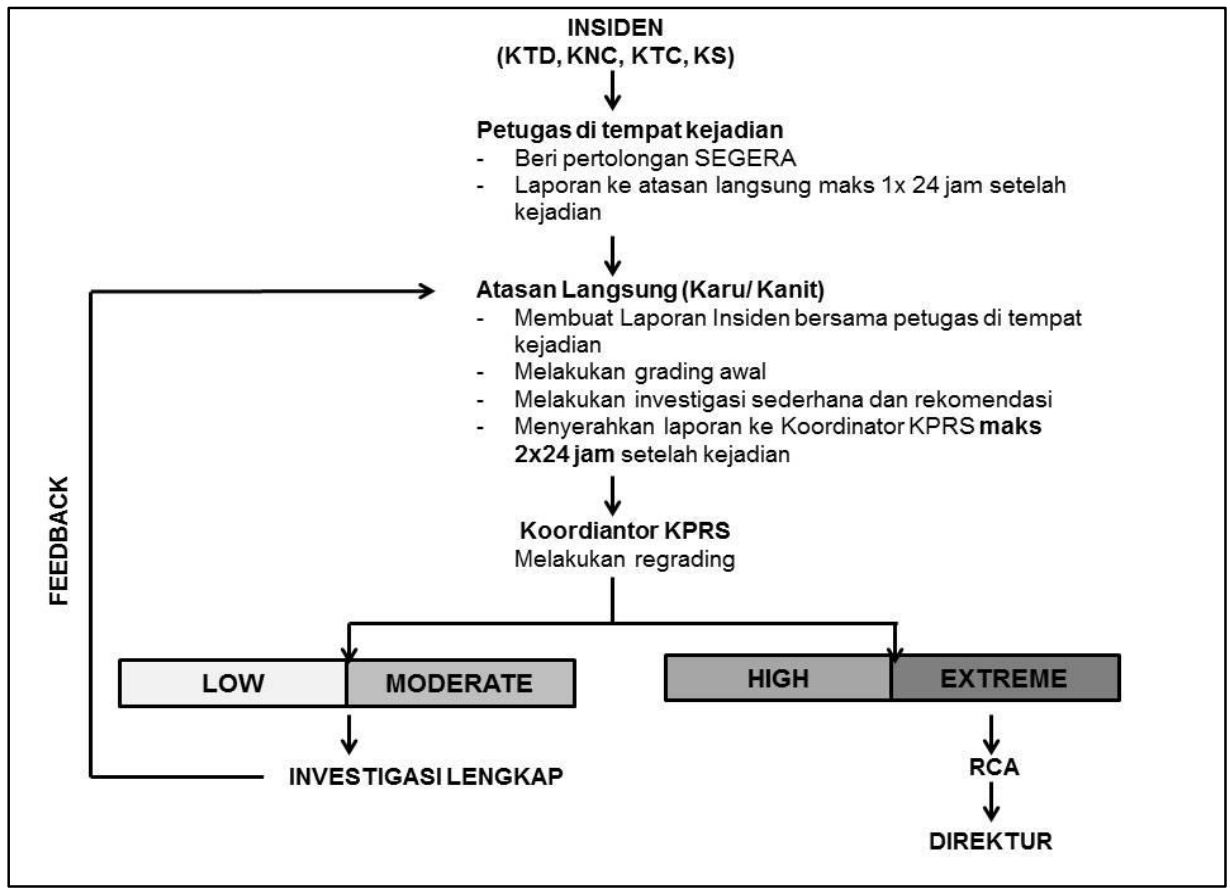

Sumber: Komite PMKP Rumah Sakit Tahun 2017

Gambar 1. Bagan Alur Pelaporan Insiden Keselamatan Pasien Rumah Sakit

\section{Evaluasi Sistem Pelaporan Insiden Keselamatan} Pasien

Pada penelitian ini, evaluasi sistem pelaporan insiden keselamatan pasien menggunakan model evaluasi Health Metrics Network (HMN) yang sudah disesuaikan dengan kebutuhan peneliti. Pada segi input dan proses terdiri dari enam aspek, sedangkan dari segi output terdiri dari tiga aspek. Kerangka evaluasi untuk sistem pelaporan insiden keselamatan pasien dijelaskan pada Gambar 2. 


\begin{tabular}{|c|c|c|}
\hline $\begin{array}{l}\text { INPUT } \\
\text { 1) Kebijakan/ Panduan } \\
\text { 2) Pendanaan } \\
\text { 3) Sumber daya manusia } \\
\text { 4) Organisasi/ Manajemen } \\
\text { 5) Metode penyelesaian masalah } \\
\text { 6) Teknologi }\end{array}$ & $\begin{array}{l}\text { PROSES } \\
\text { 1) Indikator } \\
\text { 2) Sumber data } \\
\text { 3) Pengumpulan data } \\
\text { 4) Pengolahan data } \\
\text { 5) Penyajian data } \\
\text { 6) Analisis data }\end{array}$ & $\begin{array}{l}\quad \text { OUTPUT } \\
\text { 1) Ketepatan waktu } \\
\text { 2) Kelengkapan data } \\
\text { 3) Pengambilan } \\
\text { keputusan }\end{array}$ \\
\hline $\bar{\uparrow}$ & \begin{tabular}{c}
\multicolumn{1}{c}{} \\
EVALUASI
\end{tabular} & 不 \\
\hline
\end{tabular}

Gambar 2. Kerangka Evaluasi Health Metrics Network

\section{Evaluasi Sistem Pelaporan Insiden Keselamatan Pasien dari Segi Input \\ Evaluasi sistem pelaporan insiden} keselamatan pasien dilihat dari segi input terdiri dari enam aspek. Enam aspek tersebut yaitu kebijakan atau panduan yang dimiliki oleh rumah sakit, pendanaan, sumber daya manusia (SDM), organisasi atau manajemen, metode penyelesaian masalah, dan teknologi. Rekapitulasi hasil evaluasi sistem pelaporan insiden keselamatan pasien dari segi input dijelaskan pada Tabel 1.

\section{Kebijakan/ Panduan}

Pada Peraturan Menteri Kesehatan No. 11 Tahun 2017 Pasal 5 disebutkan bahwa terdapat tujuh langkah menuju Keselamatan Pasien dan salah satunya adalah mengembangkan sistem pelaporan. Rumah sakit ini telah memiliki panduan terkait insiden keselamatan pasien yang disahkan berdasarkan SK Direksi Rumah Sakit Nomor: AY.A.SKR.1120.07.15. Panduan tersebut berjudul Panduan Insiden Keselamatan Pasien. Pada panduan tersebut terdapat prosedur pelaporan, alur pelaporan, dan formulir pelaporan insiden keselamatan pasien.

Berdasarkan hasil telaah dokumen yaitu membandingkan Panduan Insiden Keselamatan Pasien Rumah Sakit dengan Pedoman Pelaporan Insiden Keselamatan Pasien yang dikeluarkan oleh KKP-RS tahun 2015. Panduan yang dimiliki rumah sakit belum mencantumkan faktor kontributor penyebab insiden keselamatan pasien. Sedangkan faktor kontributor penyebab insiden keselamatan pasien dapat membantu para petugas dan pengambil keputusan dalam menganalisis penyebab insiden keselamatan pasien.

Pada bagan alur pelaporan insiden keselamatan pasien yang dimiliki rumah sakit ini pembuatan alur pelaporan belum sesuai kaedah pembuatan diagram alur yaitu penggunaan simbolsimbol dalam diagram alur. Pada pedoman yang dikeluarkan KKP-RS tahun 2015 terdapat contoh bagan alur pelaporan insiden keselamatan di rumah sakit, akan tetapi Rumah sakit masih menggunakan penjelasan dan belum jelas siapa yang bertanggung jawab pada setiap tahapan di alur pelaporan.

Berdasarkan hasil wawancara dengan informan utama 1, informan utama 3, dan informan penunjang, didapatkan kesimpulan bahwa laporan insiden keselamatan pasien langsung diserahkan kepada Sekretaris Komite PMKP atau Ketua Komite PMKP. Pembuatan laporan insiden masih dilimpahkan kepada kepada satu petugas. Hal tersebut belum sesuai dengan kebijakan yang berlaku di rumah sakit tersebut dimana petugas yang menemukan insiden wajib terlibat dalam pembuatan laporan insiden dan laporan tersebut diserahkan kepada koordinator keselamatan pasien rumah sakit. Pembuatan kebijakan merupakan hal yang penting karena sebagai tata cara yang benar untuk dilakukan guna menyelesaikan suatu proses kerja tertentu (Sanjaya et al., 2017).

Pada aspek pendanaan, rumah sakit ini tidak memberikan dana secara tunai kepada Komite PMKP dalam pembuatan laporan insiden keselamatan pasien setiap triwulan. Pendanaan telah dicairkan dan dibelanjakan untuk fasilitas yang menunjang berupa seperangkat komputer, printer, dan kertas dari manajemen. Pada laporan insiden keselamatan pasien setiap triwulan terdapat informasi penting bagi para pengambil keputusan untuk proses pembelajaran. Dalam penyusunan informasi kesehatan, diperlukan dana untuk menunjang sebuah sistem informasi yang komprehensif terutama untuk melakukan pengumpulan data, olah data, dan analisis data (WHO, 2008).

Aspek pendanaan sistem pelaporan insiden di rumah sakit ini telah sesuai dengan ketentuan yang dikeluarkan oleh World Health Organization bahwa telah ada dana yang mampu mendukung sebuah sistem informasi kesehatan walaupun dana tersebut tidak diberikan secara langsung atau tunai.

Rumah sakit ini telah memiliki Champion mutu dan keselamatan pasien di setiap unit kerja. Champion mutu dan keselamatan pasien di setiap unit yang bertugas melakukan monitoring terhadap jalannya program-program keselamatan pasien di masing-masing unit. Masih banyak petugas yang belum paham tentang sistem pelaporan insiden keselamatan pasien. $\mathrm{Hal}$ tersebut ditunjukkan dengan petugas yang hanya mengisi laporan insiden di buku insiden di setiap unit yang kemudian dalam pembuatan laporan di formulir pelaporan yang melakukan adalah petugas yang memahaminya. Selain itu, semua petugas yang ada di setiap unit telah diberikan sosialisasi tentang sistem pelaporan keselamatan pasien. 
Tabel 1. Rekapitulasi Hasil Evaluasi Sistem Pelaporan Insiden Keselamatan Pasien dari Segi Input

\begin{tabular}{|c|c|c|c|}
\hline $\begin{array}{l}\text { Komponen } \\
\text { Evaluasi } \\
\text { berdasarkan } \\
\text { Model HMN }\end{array}$ & $\begin{array}{c}\text { Pelaksanaan Sistem } \\
\text { Pelaporan Insiden } \\
\text { Keselamatan Pasien di } \\
\text { Rumah sakit }\end{array}$ & $\begin{array}{l}\text { Kesesuaian dengan } \\
\text { Kebijakan dan teori }\end{array}$ & Hambatan \\
\hline $\begin{array}{l}\text { a. Kebijakan/ } \\
\text { Panduan }\end{array}$ & $\begin{array}{l}\text { Adanya Panduan Insiden } \\
\text { Keselamatan Pasien yang } \\
\text { disahkan berdasarkan SK } \\
\text { Direksi Rumah Sakit Nomor: } \\
\text { AY.A.SKR.1120.07.15 }\end{array}$ & $\begin{array}{l}\text { Belum sesuai dengan } \\
\text { Pedoman Pelaporan } \\
\text { Insiden Keselematan } \\
\text { Pasien KKP-RS tahun } \\
\text { 2015. Ketidaksesuaian } \\
\text { tersebut ada pada bagan } \\
\text { alur pelaporan dan belum } \\
\text { ada faktor kontributor } \\
\text { penyebab insiden } \\
\text { keselamatan pasien }\end{array}$ & $\begin{array}{l}\text { Pembuatan bagan alur } \\
\text { pelaporan belum } \\
\text { sesuai dengan kaedah } \\
\text { pembuatan diagram } \\
\text { alur pelaporan. } \\
\text { Pada pelaksanaan } \\
\text { sistem pelaporan } \\
\text { insiden keselamatan } \\
\text { pasien, para petugas } \\
\text { belum mampu } \\
\text { mengklasifikasikan } \\
\text { insiden berdasarkan } \\
\text { tipe dan sub tipe } \\
\text { insiden }\end{array}$ \\
\hline b. Pendanaan & $\begin{array}{l}\text { Pendanaan untuk pembuatan } \\
\text { laporan telah ada. Namun, } \\
\text { tidak diberikan secara tunai } \\
\text { kepada Komite PMKP. Dana } \\
\text { yang ada dibelanjakan dengan } \\
\text { memberikan fasilitas penunjang }\end{array}$ & $\begin{array}{l}\text { Pada aspek pendanaan } \\
\text { telah sesuai dengan } \\
\text { ketentuan teori HMN } \\
\text { bahwa penyususunan } \\
\text { informasi kesehatan, } \\
\text { diperlukan dana untuk } \\
\text { menunjang sebuah sistem } \\
\text { informasi }\end{array}$ & Tidak ada hambatan. \\
\hline $\begin{array}{l}\text { c. Sumber Daya } \\
\text { Manusia }\end{array}$ & $\begin{array}{l}\text { Para petugas di rumah sakit } \\
\text { telah diberikan sosialisasi } \\
\text { terkait sistem pelaporan insiden } \\
\text { keselamatan pasien }\end{array}$ & $\begin{array}{l}\text { Ketersediaan sumber } \\
\text { daya manusia untuk } \\
\text { sistem pelaporan insiden } \\
\text { keselamatan pasien di } \\
\text { rumah sakit sudah sesuai } \\
\text { dengan kebijakan yang } \\
\text { berlaku }\end{array}$ & $\begin{array}{l}\text { Masih adanya petugas } \\
\text { yang belum paham } \\
\text { akan sistem pelaporan } \\
\text { insiden keselamatan } \\
\text { pasien, walaupun } \\
\text { sosisalisasi telah } \\
\text { diberikan }\end{array}$ \\
\hline $\begin{array}{l}\text { d. Organisasi/ } \\
\text { Manajemen }\end{array}$ & $\begin{array}{l}\text { Telah adanya tim Keselamatan } \\
\text { Pasien Rumah Sakit yang } \\
\text { bertanggung jawab akan } \\
\text { sistem pelaporan insiden } \\
\text { keselamatan pasien di rumah } \\
\text { sakit }\end{array}$ & $\begin{array}{l}\text { Sudah sesuai dengan } \\
\text { Permenkes No } 11 \text { Tahun } \\
2017 \text { tentang } \\
\text { Keselamatan Pasien }\end{array}$ & $\begin{array}{l}\text { Laporan insiden } \\
\text { keselamatan pasien } \\
\text { masih sering sering } \\
\text { diserahkan kepada } \\
\text { Sekretaris atau Ketua } \\
\text { PMKP bukan kepada } \\
\text { koordinator } \\
\text { keselamatan pasien } \\
\text { rumah sakit }\end{array}$ \\
\hline $\begin{array}{l}\text { e. Metode } \\
\text { Penyelesaian } \\
\text { masalah }\end{array}$ & $\begin{array}{l}\text { Metode penyelesaian masalah } \\
\text { menggunakan metode PDCA } \\
\text { (Plan, Do, Check, Action) }\end{array}$ & $\begin{array}{l}\text { Belum sesuai dengan teori } \\
\text { yang ada. Metode yang } \\
\text { digunakan seharusnya } \\
\text { PDSA (Plan, Do, Study, } \\
\text { Action) }\end{array}$ & $\begin{array}{l}\text { Belum paham akan } \\
\text { penggunaan metode } \\
\text { yang tepat dalam } \\
\text { penyelesaian masalah } \\
\text { keselamatan pasien }\end{array}$ \\
\hline f. Teknologi & $\begin{array}{l}\text { Pelaporan insiden masih dalam } \\
\text { bentuk formulir yang ditulis } \\
\text { tangan. Akan tetapi dalam } \\
\text { pengolahan data telah dibantu } \\
\text { dengan aplikasi Ms. Excell dan } \\
\text { Epi Info }\end{array}$ & $\begin{array}{l}\text { Sudah sesuai dengan } \\
\text { teori tentang Health } \\
\text { Metrics Networks bahwa } \\
\text { perlu adanya teknologi } \\
\text { yang mampu } \\
\text { mempercepat proses } \\
\text { analisis data }\end{array}$ & $\begin{array}{l}\text { Pelaporan insiden yang } \\
\text { masih dalam bentuk } \\
\text { manual atau } \\
\text { penggunaan formulir } \\
\text { yang membuat laporan } \\
\text { telat diterima oleh tim } \\
\text { keselamatan pasien } \\
\text { rumah sakit }\end{array}$ \\
\hline
\end{tabular}


"Sosialisasi kita berikan untuk seluruh petugas rumah sakit, baik dari petugas pelayanan hingga non pelayanan. Waktu pelaksanaannya setahun sekali sekitar bulan Maret dan April" (Informan Utama 1, 47 tahun)

\begin{abstract}
"Sebenarnya,semua petugas di setiap unit udah diberikan sosialisasi tentang pelaporan insiden keselamatan pasien. Cuma pemahaman dan rasa tanggung jawab setiap petugas beda-beda apalagi jika banyaknya kerjaan dan formulir laporan yang terlalu banyak yang harus diisi, meraka merasa hal itu jadi beban tambahan." (Informan Penunjang, 25 tahun)
\end{abstract}

Keterbatasan sumber daya dan kurangnya pelatihan petugas atau faktor manusia dalam investigasi inisiden membuat sistem pelaporan insiden sering kali tidak mampu untuk dilakukan analisis yang lebih mendalam atau menghasilkan intervensi yang kuat untuk mengurangi risiko (Pham et al., 2013). Rumah sakit ini perlu melakukan pembinaan dan pengembangan terhadap para petugas agar sistem pelaporan insiden keselamatan pasien dapat berjalan sesuai dengan kebijakan yang telah dibuat oleh manajemen rumah sakit.

Upaya pembinaan dan pengembangan sumber daya manusia di rumah sakit sangat diperlukan. Upaya tersebut dapat dilakukan dengan adanya sosialisasi atau pelatihan terkait keselamatan pasien yang dapat dilakukan secara rutin. Manfaat dari upaya tersebut yaitu agar rumah sakit memilki sumber daya manusia yang mampu membantu organisasi dalam mencapai tujuan.

Rumah sakit telah memiliki struktur organisasi untuk melaksanakan program keselamatan pasien. Tim Keselamatan Pasien Rumah Sakit termasuk ke dalam bagian Komite PMKP Rumah Sakit dan terdiri dari koordinator keselamatan pasien rumah sakit, anggota, serta Champion mutu.

Rumah sakit ini belum menggunakan metode PDSA (Plan, Do, Study, Action) dalam penyelesaian masalah. Pedoman pelaporan memberikan peluang tentang transparansi isu kesehatan sehingga dapat membangun pengetahuan tentang bagaimana menggunakan metode PDSA yang efektif serta prinsip-prinsip untuk meningkatkan peluang keberhasilan. Metode PDSA diharapkan mampu diimplementasikan sesuai dengan pedoman siklus yang disusun oleh pendiri. Metode PDSA harus diimplementasikan dengan konsistensi yang lebih besar. Hasil dari penggunaan PDSA untuk pembelajaran dan perbaikan mutu sehingga dapat mewujudkan tujuan dari Komite PMKP yaitu peningkatan mutu dan terjaminnya keselamatan pasien (Taylor, 2013).

Metode penyelesaian dengan menggunakan PDCA hanya mampu sebatas memeriksa apakah perencanaan dan pelaksanaan sudah sesuai tetapi tidak bisa dijadikan pembelajaran. Hal ini terjadi tidak adanya kegiatan yang menggali lebih dalam terkait faktor yang menjadi penyebab pelaksanaan tidak sesuai dengan perencanaan. Pada metode PDSA terdapat proses pembelajaran dimana hal tersebut sesuai dengan tujuan dari sistem pelaporan insiden keselamatan pasien bahwa hasil dari pelaporan dijadikan pembelajaran bagi individu dan organisasi dalam proses perbaikan pelayanan kesehatan yang diberikan kepada pasien.

Seluruh anggota organisasi saling berkoordinasi agar program keselamatan pasien berjalan dengan baik. Salah satu kegiatan dari koordinasi tersebut adalah mengadakan rapat rutin mingguan dan bulanan yang bertujuan untuk menyampaikan hasil pemantauan dan evaluasi terhadap pelaksanaan program keselamatan pasien. Akan tetapi, pelaporan insiden keselamatan pasien belum seutuhnya berjalan sesuai dengan alur pelaporan yang telah ada. Laporan insiden keselamatan pasien masih sering diserahkan kepada Sekretaris atau Ketua PMKP bukan kepada koordinator keselamatan pasien rumah sakit.

Hasil evaluasi sistem pelaporan insiden keselamatan pasien pada aspek organisasi atau managemen sejalan dengan penelitian Hakim dan Pudjihardjo (2014) bahwa keselamatan pasien adalah program kerja yang melibatkan banyak unit kerja di rumah sakit secara holistik sehingga dibutuhkan koordinasi antar unit untuk mencapai tujuan program secara optimal. Selain itu, dibutuhkan komitmen direksi, manajemen, dan tim keselamatan pasien rumah sakit untuk memantau dan mengevaluasi pelaporan insiden dengan cara visitasi secara pperiodicdan melakukan rapat yang diadakan tiap bulan (Adrini T et al., 2015).Agar program keselamatan pasien dapat berjalan optimal, koordinasi secara rutin dan komitmen yang kuat dari segala pihak dibutuhkan agar program keselamatan pasien berjalan dengan baik terutama pada proses pelaporan insiden keselamatan pasien.

Sistem pelaporan insiden keselamatan pasien rumah sakit ini menggunakan metode penyelesaian masalah dengan metode PDCA (Plan, Do, Check, Action). Hasil analisis plan pada indikator ketepatan waktu pelaporan insiden keselamatan pasien dalam $2 \times 24$ jam tercapai $100 \%$. Ketepatan waktu pelaporan pada do dalam $2 \times 24$ jam belum memenuhi standar $100 \%$ dengan hasil bulan April sebesar $28,1 \%$, bulan Mei sebesar $65,0 \%$, dan bulan Juni sebesar $42,1 \%$. Analisis check tidak tercapai karena keterlambatan penulisan laporan di form insiden dan keterlambatan penyerahan form insiden ke Komite PMKP. Sebagian besar insiden ditemukan di unit Farmasi sehingga membutuhkan waktu untuk penulisan laporan serta penyerahannya ke Komite PMKP. Sedangkan pada aspek action yaitu pendisiplinan pelaporan insiden, komite PMKP aktif menanyakan progres, dan penulisan laporan insiden tidak ditanggungjawabkan hanya pada 1 orang saja, tetapi pada siapa yang menemukan insiden tersebut. Pelaporan insiden keselamatan pasien di rumah sakit ini masih secara manual yaitu menggunakan formulir laporan insiden keselamatan pasien yang ditulis tangan. Formulir laporan insiden 
kemudian diserahkan kepada komite PMKP untuk dilakukan pengolahan data. Pengolahan data menggunakan program Ms. Excel dan Epi Info untuk menunjang penyusunan laporan insiden keselamatan pasien setiap tiga bulan sekali.

Teknologi sistem informasi dapat sangat membantu suatu organisasi yang komplek seperti institusi pelayanan kesehatan di mana institusi pelayanan kesehatan berada di bawah tekanan dari penerima jasa pelayanan kesehatan. Adanya teknologi dapat membantu meningkatkan keuntungan bagi organisasi (Handayani et al., 2013).

\section{Evaluasi Sistem Pelaporan Insiden Keselamatan Pasien dari Segi Proses}

Evaluasi sistem pelaporan insiden keselamatan pasien dilihat dari segi proses terdiri dari enam aspek yaitu indikator, sumber data, pengumpulan data, pengolahan data, penyajian data, dan analisis data. Rekapitulasi hasil evaluasi sistem pelaporan insiden keselamatan pasien dari segi proses dijelaskan pada Tabel 2.

Berdasarkan Keputusan Menteri Kesehatan Republik Indonesia Nomor 129 tahun 2008 tentang Standar Pelayanan Minimal Rumah Sakit bahwa angka dari insiden keselamatan pasien di rumah sakit seharusnya $0 \%$ atau dapat diartikan tidak adanya kejadian yang dapat membahayakan pasien seperti kejadian pasien jatuh, kesalahan obat, dan kesalahan penyerahan hasil pemeriksaan.

Hasil pelaporan insiden keselamatan pasien triwulan 2 tahun 2017 di rumah sakit ini didapatkan bahwa jenis insiden keselamatan pasien yang dilaporkan ada empat dimensi yaitu Kejadian Nyaris Cedera (KNC), Kejadian Tidak Cedera (KTC), Kejadian Tidak Diharapkan (KTD), dan Sentinel. Selama Bulan April hingga Juni tahun 2017 Kejadian Nyaris Cidera (KNC) sebanyak 54 insiden, Kejadian Tidak Cedera (KTC) sebanyak 14, Kejadian Tidak Diharapkan (KTD) sebanyak 3 insiden, dan tidak ada kejadian sentinel. Pada Triwulan 2 tahun 2017 jumlah insiden sebanyak 71 insiden. Walaupun KTD sedikit dan tidak ada sentinel, pelaporan harus tetap dilakukan karena dapat dijadikan data untuk pencegahan dan data tersebut dapat digunakan untuk meningkatkan mutu pelayanan rumah sakit.

Sumber data yang digunakan untuk menyusun laporan insiden keselamatan pasien di rumah sakit bersumber dari formulir laporan insiden yang diserahkan ke sub komite keselamatan pasien. Formulir laporan bersifat rahasia dan hanya pihak berwenang yang dapat mengakses data tersebut.

Sumber data yang digunakan ini telah sesuai dengan dengan pedoman pelaporan insiden keselamatan pasien yang dikeluarkan oleh KKP-RS tahun 2015 dan panduan insiden keselamatan pasien yang dimiliki. Data penyusunan laporan insiden keselamatan pasien berasal dari formulir laporan insiden. Menurut Elliot, Martin, dan Neville (2014), pengembangan sistem pencatatan dan pelaporan insiden keselamatan pasien harus dilakukan dengan cara anonim, rahasia, dan dapat digunakan secara multiuser secara bersamaan. Oleh karena itu, dapat disimpulkan sumber data yang yang digunakan pada pelaporan indisen telah sesuai dengan ketentuan yang berlaku pada pedoman dan panduan insiden keselamatan pasien.

\section{Pengumpulan Data}

Pengumpulan data tentang insiden keselamatan pasien dilakukan dengan menemukan adanya insiden melaporkan insiden tersebut dengan menulis di formulir laporan insiden keselamatan pasien yang kemudian diserahkan ke sub komite keselamatan pasien. Data ini dilaporkan dalam waktu $2 \times 24$ jam. Data yang dikumpulkan untuk menyusun laporan antara lain data pasien, rincian kejadian, hasil grading risiko, hasil investigasi sederhana untuk grading risiko biru dan hijau.

Pengumpulan dan pengambilan data harus valid (akurat, tepat waktu, lengkap, dan dapat dipercaya) karena digunakan untuk menganilisis tren, menilai peningkatan pelayanan, dan membandingkan perbedaan cara pelayanan (WHO, 2008).

Data insiden yang dilaporkan oleh rumah sakit sudah akurat karena sesuai dengan yang terjadi pada saat terjadi insiden. Data yang dilaporkan juga telah lengkap karena sebagian besar data telah berisi aspek-aspek yang harus dilaporkan dan sesuai dengan formulir laporan insiden keselamatan pasien walaupun pada saat terjadinya insiden, laporan belum ditulis secara langsung di formulir laporan insiden keselamatan pasien.

Data insiden yang dikumpulkan dapat dikatakan dipercaya karena pada saat kejadian, petugas yang menemukan insiden segera melaporkan kepada kepala ruangan atau unit untuk segera diselesaikan dan dibuat laporan tertulis. Akan tetapi, masih adanya laporan insiden keselamatan yang belum tepat waktu diserahkan kepada koordinator keselamatan pasien rumah sakit.

Pelaksanaan pengumpulan data melalui komputer dengan berbasis sistem informasi di negara berkembang belum sepenuhnya dilakukan dengan baik. Masalah umum yaitu sumber daya yang kurang, jumlah dan kapasitas petugas, infrastruktur, intregasi dan distribusi data, survei peraturan, dan pendekatan regional (Nurmansyah et al., 2015). Data yang dikumpulkan dapat dikatakan kurang valid karena masih ada aspek yang belum terpenuhi yaitu ketepatan waktu pengumpulan dan pengambilan data.

Pengolahan data merupakan sebuah proses untuk mendapatkan data dari setiap variabel yang diteliti untuk dapat dianalisis. Pada Panduan Insiden Keselamatan Pasien Rumah Sakit belum disebutkan tentang teknik pengolahan data insiden keselamatan pasien maupun aplikasi untuk mengolah data yang digunakan. Sedangkan berdasarkan hasil observasi, proses pengolahan data menggunakan program Epi Info dan Ms. Excel untuk mengetahui distribusi frekuensi setiap jenis insiden keselamatan, tempat terjadinya insiden, kategori insiden yang terjadi, dan hasil grading dari setiap insiden. Proses pengolahan data tentang insiden keselamatan pasien telah terkomputerisasi. 
Tabel 2. Rekapitulasi Hasil Evaluasi Sistem Pelaporan Insiden Keselamatan Pasien dari Segi Proses

\begin{tabular}{|c|c|c|c|}
\hline $\begin{array}{l}\text { Komponen } \\
\text { Evaluasi } \\
\text { berdasarkan } \\
\text { Model HMN } \\
\end{array}$ & $\begin{array}{l}\text { Pelaksanaan Sistem Pelaporan } \\
\text { Insiden Keselamatan Pasien di } \\
\text { Rumah Sakit tempat penelitian }\end{array}$ & $\begin{array}{l}\text { Kesesuaian dengan Kebijakan } \\
\text { dan teori }\end{array}$ & Hambatan \\
\hline a. Indikator & $\begin{array}{l}\text { Adanya pelaporan tentang jenis } \\
\text { insiden KTD, KNC, KTD, dan } \\
\text { sentinel. }\end{array}$ & $\begin{array}{l}\text { Sudah sesuai dengan } \\
\text { Permenkes RI No. } 11 \text { Tahun } \\
2017 \text { dan Pedoman Pelaporan } \\
\text { Insiden Keselamatan Pasien } \\
\text { KKP-RS tahun } 2015 .\end{array}$ & $\begin{array}{l}\text { Tidak ada } \\
\text { hambatan. }\end{array}$ \\
\hline b. Sumber data & $\begin{array}{l}\text { Formulir laporan insiden yang } \\
\text { diserahkan ke sub komite } \\
\text { keselamatan pasien }\end{array}$ & $\begin{array}{l}\text { Sudah sesuai dengan dengan } \\
\text { pedoman pelaporan insiden } \\
\text { keselamatan pasien yang } \\
\text { dikeluarkan oleh KKP-RS tahun } \\
2015\end{array}$ & $\begin{array}{l}\text { Tidak ada } \\
\text { hambatan }\end{array}$ \\
\hline $\begin{array}{l}\text { c. Pengumpulan } \\
\text { data }\end{array}$ & $\begin{array}{l}\text { Petugas yang menemukan } \\
\text { adanya insiden melaporkan } \\
\text { insiden tersebut dengan menulis } \\
\text { pada formulir laporan insiden } \\
\text { keselamatan pasien yang } \\
\text { kemudian diserahkan ke sub } \\
\text { komite keselamatan pasien dan } \\
\text { dilaporkan dalam waktu } 2 \times 24 \\
\text { jam }\end{array}$ & $\begin{array}{l}\text { Belum sesuai dengan ketentuan } \\
\text { WHO tahun } 2008 \text { bahwa } \\
\text { pengumpulan dan pengambilan } \\
\text { data harus valid }\end{array}$ & $\begin{array}{l}\text { Data yang } \\
\text { dikumpulkan } \\
\text { belum tepat } \\
\text { waktu }\end{array}$ \\
\hline d. Pengolahan data & $\begin{array}{l}\text { Pada panduan pelaporan rumah } \\
\text { sakit belum dijelaskan tentang } \\
\text { teknik pengolahan data akan } \\
\text { tetapi pada pelaksanaannya } \\
\text { proses pengolahan data } \\
\text { menggunakan program Epi Info } \\
\text { dan Ms. Excel }\end{array}$ & $\begin{array}{l}\text { Sudah sesuai dengan teori HMN } \\
\text { bahwa penggunaan teknologi } \\
\text { yang digunakan dapat } \\
\text { mendukung proses pengolahan } \\
\text { data. }\end{array}$ & $\begin{array}{l}\text { Tidak ada } \\
\text { hambatan. }\end{array}$ \\
\hline e.Penyajian data & $\begin{array}{l}\text { Penyajian data disajikan dalam } \\
\text { bentuk tabel dan diagram. Hasil } \\
\text { laporan insiden yang disajikan } \\
\text { yaitu tentang jenis insiden, unit } \\
\text { kerja penyebab insiden, kategori } \\
\text { insiden, rekapitulasi insiden }\end{array}$ & $\begin{array}{l}\text { Belum sesuai dengan Panduan } \\
\text { Rumah Sakit dan Pedoman } \\
\text { Pelaporan Insiden Keselamatan } \\
\text { Pasien KKP-RS tahun } 2015\end{array}$ & $\begin{array}{l}\text { Ada kendala } \\
\text { pada } \\
\text { penentuan } \\
\text { insiden ke } \\
\text { dalam tipe dan } \\
\text { subtipe insiden }\end{array}$ \\
\hline f. Analisis data & Analisis matriks grading & $\begin{array}{l}\text { Analisis data telah sesuai } \\
\text { dengan Panduan Insiden } \\
\text { Keselamatan Pasien Rumah } \\
\text { sakit dan Pedoman Pelaporan } \\
\text { Insiden Keselamatan Pasien } \\
\text { KKP-RS tahun } 2015\end{array}$ & $\begin{array}{l}\text { Tidak ada } \\
\text { hambatan }\end{array}$ \\
\hline
\end{tabular}

Pengolahan data menggunakan program komputer dapat mengurangi tingkat kesalahan yang ada dan dapat diolah lebih lanjut. Dengan demikian dapat dikatakan bahwa rumah sakit ini telah melakukan pengolahan data sesuai dengan teori yang ada agar mengurangi kesalahan dalam pelaporan insiden keselamatan pasien.

Penyajian data dapat disajikan dalam bentuk tabel frekuensi, gambar, maupun grafik. Pada panduan insiden keselamatan pasien rumah sakit ini tidak disebutkan ketentuan dalam penyajian data. Pada panduan hanya dijelaskan tentang hasil yang perlu disajikan pada laporan insiden keselamatan pasien. Salah satu hasil yang harus disajikan dalam laporan insiden keselamatan pasien yaitu tipe insiden. Akan tetapi, hasil telaah dokumen laporan insiden keselamatan pasien triwulan rumah sakit, penyajian data tipe insiden disebutkan dengan

istilah kategori insiden. Hal tersebut tidak sesuai dengan panduan insiden keselamatan pasien rumah sakit ini.

Menurut hasil wawancara dengan informan, masih ada kendala pada penentuan insiden termasuk ke dalam tipe dan sub-tipe insiden. Penyajian data pada laporan insiden keselamatan pasien triwulan rumah sakit ini dibuat dengan menggunakan istilah yang lebih mudah dipahami. Selain hal tersebut, belum terklasifikasikannya insiden ke dalam tipe dan sub tipe insiden keselamatan pasien. Penyebab insiden keselamatan pasien juga belum dicantumkan berdasarkan faktor kontributor penyebab insiden keselamatan pasien. 
Penyajian data pada laporan insiden keselamatan pasien triwulan rumah sakit menggunakan tabel yang kemudian diberikan narasi.

Pelaporan insiden keselamatan pasien yang dibuat sudah dilakukan analisis dengan cara menganalisis dampak risiko dari insiden yang terjadi serta analisis frekuensi atau probabilitas insiden. Berdasarkan pedoman yang dikeluarkan oleh KKPRS tahun 2015 dan panduan insiden keselamatan pasien rumah sakit ini, analisis yang digunakan untuk data insiden keselamatan pasien menggunakan analisis matriks grading. Analisis yang dilakukan oleh rumah sakit telah sesuai dengan panduan insiden keselamatan pasien rumah sakit ini dan pedoman pelaporan insiden keselamatan pasien yang dikeluarkan oleh Komite Keselamatan Pasien Rumah Sakit pada tahun 2015. Hasil analisis data harus sesuai dengan tujuan adanya sistem pelaporan dan dapat memenuhi kebutuhan organisasi. Hasil analisis data nantinya akan menjadi informasi penting bagi organisasi terutama untuk pengambilan keputusan dan mendukung untuk proses pembelajaran.

\section{Evaluasi Sistem Pelaporan Insiden Keselamatan Pasien dari Segi Output}

Evaluasi sistem pelaporan insiden keselamatan pasien dilihat dari segi output terdiri dari tiga aspek yaitu ketepatan waktu, kelengkapan data, dan pengambilan keputusan. Rekapitulasi hasil evaluasi sistem pelaporan insiden keselamatan pasien dari segi output dijelaskan pada Tabel 3.

Ketepatan waktu menurut WHO tahun 2008 adalah periode pengumpulan data dan ketersediaanya ke tingkat yang lebih tinggi atau saat data tersebut dipublikasi. Berdasarkan ketepatan waktu pelaporan, rumah sakit ini belum mampu melakukan kewajibannya sesuai dengan Peraturan Menteri Kesehatan Nomor 11 tahun 2017. Pada Pasal 18 disebutkan bahwa setiap insiden harus dilaporkan kepada tim Keselamatan Pasien Rumah Sakit (internal) dalam waktu paling lambat 2x24 jam. Hal tersebut terbukti dari grafik ketepatan waktu pelaporan insiden keselamatan pasien dalam $2 \times 24$ jam pada triwulan kedua atau pada April sampai dengan Juni Tahun 2017. Ketepatan waktu pelaporan insiden keselamatan pasien tersebut dijadikan sebagai indikator mutu kunci tahun 2017 yaitu indikator mutu kunci area manajemen nomor dua yaitu indikator pelaporan kegiatan yang diwajibkan oleh peraturan perundang-undangan.

\section{Ketepatan waktu pelaporan insiden} keselamatan pasien dalam 2 × 24 jam

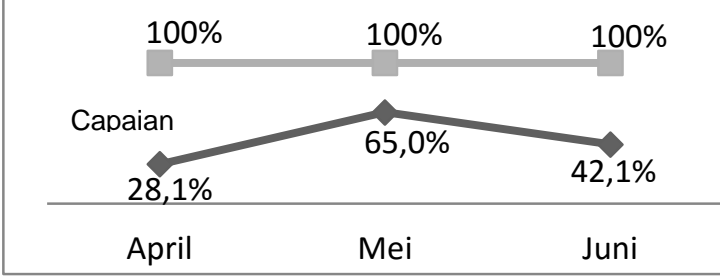

Sumber: Komite PMKP Rumah Sakit Tahun 2017
Gambar 3. Ketepatan waktu pelaporan insiden keselamatan pasien dalam 2x24 jam

Berdasarkan Gambar 3 dapat diketahui bahwa waktu pelaporan insiden keselamatan pasien lebih dari $2 \times 24$ (dua kali dua puluh empat) jam.

"Setiap ada insiden sebenarnya langsung diselesaikan saat itu juga oleh kepala ruang dan Champion mutu dan keselamatan pasien di unit terjadinya insiden, cuma memang untuk penulisan laporan insiden di formulir insiden keselamatan pasien biasanya ga langsung karena tidak ada waktu." (Informan utama 1, 47 tahun)

"Laporan insiden keselamatan pasien ga bisa langsung dibuat dan diserahkan ke Komite PMKP karena masih banyaknya kerjaan yang lain, antrian pasien yang panjang, waktu shift udah habis, dan petugas pada males menulis laporan yang harus manual di formulir insiden. Jadi kalau ada insiden kita catat dulu di buku baru nanti disalin ke formulir. Insiden juga kejadian yang sama dan sering terjadi jadi kadang males menulis hal yang sama." (Informan utama 3, 25 tahun)

\section{"Unit yang sering telat menyerahkan laporan insiden karena yang menulis laporan diserahkan ke satu petugas aja, sedangkan beban kerja petugas tersebut juga sudah berat ditambah tugas yang seharusnya menjadi tanggung jawab setiap petugas ketika menemukan insiden." (Informan penunjang, 25 tahun)}

Berdasarkan jawaban dari para informan dapat ditarik kesimpulan bahwa yang menjadi penyebab tidak tepat waktunya pelaporan insiden yaitu tidak ada waktu untuk menuliskan laporan insiden. Para petugas sudah mengetahui tentang pelaporan insiden hanya saja masih menyerahkan tugas untuk menuliskan laporan insiden ke satu orang saja dikarenakan masih adanya tugas lain yang harus diselesaikan. Beban kerja yang tinggi dan kurangnya sumber daya manusia membuat petugas merasa kelelahan dalam bekerja sehingga sering telat dalam menuliskan laporan dan menyerahkan laporan insiden. Formulir insiden yang berbentuk manual (tulis tangan) membuat petugas membutuhkan waktu untuk menulis laporan insiden. Adanya insiden yang sama membuat petugas merasa jenuh harus melaporkan hal yang serupa berkali-kali.

Hal tersebut didukung dengan hasil penelitian Kurniavip dan Damayanti (2017) yang menyatakan bahwa kelelahan saat kerja lebih cenderung terdapat hubungan dengan insiden keselamatan pasien. Jika petugas merasa kelelahan dalam bekerja, maka pada saat terjadi insiden dan petugas tersebut telat melaporkan insiden dapat menyebabkan insiden yang sama terulang atau insiden baru. Keluhan yang disampaikan oleh para petugas sesuai dengan hasil penelitian Arfan, Pasinringi, dan Sidin (2013), penyebab kelelahan karena tidak sesuai antara 
jumlah pegawai yang ada dengan beban kerja di unit kerja. Telatnya pelaporan insiden keselamatan pasien, bisa berdampak pada telatnya tindak lanjut terhadap insiden tersebut dan program keselamatan pasien dalam rangka adanya pencegahan terhadap insiden keselamatan pasien pun dapat terhambat.

Tabel 3. Rekapitulasi Hasil Evaluasi Sistem Pelaporan Insiden Keselamatan Pasien dari Segi Output

\begin{tabular}{|c|c|c|c|}
\hline $\begin{array}{l}\text { Komponen } \\
\text { Evaluasi } \\
\text { berdasarkan } \\
\text { Model HMN }\end{array}$ & $\begin{array}{c}\text { Pelaksanaan Sistem } \\
\text { Pelaporan Insiden } \\
\text { Keselamatan Pasien di } \\
\text { Rumah Sakit Tempat } \\
\text { Penelitian } \\
\end{array}$ & $\begin{array}{l}\text { Kesesuaian dengan } \\
\text { Kebijakan dan Teori }\end{array}$ & Hambatan \\
\hline $\begin{array}{l}\text { a. Ketepatan } \\
\text { waktu }\end{array}$ & $\begin{array}{l}\text { Pelaporan insiden } \\
\text { keselamatan pasien belum } \\
\text { dilaporkan dalam waktu } 2 \times 24 \\
\text { jam }\end{array}$ & $\begin{array}{l}\text { Ketepatan waktu belum sesuai } \\
\text { dengan Permenkes RI No. } 11 \\
\text { tahun } 2017 \text { tentang } \\
\text { Keselamatan Pasien. Pada } \\
\text { Pasal } 18 \text { disebutkan bahwa } \\
\text { setiap insiden harus } \\
\text { dilaporkan kepada tim } \\
\text { Keselamatan Pasien Rumah } \\
\text { Sakit (Internal) dalam waktu } \\
\text { paling lambat } 2 \times 24 \text { jam. }\end{array}$ & $\begin{array}{l}\text { Adanya faktor dari } \\
\text { petugas yang tidak } \\
\text { ada waktu dalam } \\
\text { melaporkan karena } \\
\text { beban kerja yang } \\
\text { tinggi dan pembuatan } \\
\text { laporan masih } \\
\text { manual (tulis tangan) }\end{array}$ \\
\hline $\begin{array}{l}\text { b. Kelengkapan } \\
\text { data }\end{array}$ & $\begin{array}{l}\text { Kelengkapan data pada } \\
\text { laporan insiden keselamatan } \\
\text { pasien dapat dilihat dari aspek } \\
\text { yang harus dilengkapi pada } \\
\text { formulir laporan insiden } \\
\text { keselamatan pasien rumah } \\
\text { sakit }\end{array}$ & $\begin{array}{l}\text { Kelengkapan data telah sesuai } \\
\text { dengan ketentuan yang ada } \\
\text { pada panduan insiden } \\
\text { keselamatan pasien rumah } \\
\text { sakit ini dan Pedoman } \\
\text { Pelaporan Insiden } \\
\text { Keselamatan Pasien KKP-RS } \\
\text { tahun } 2015\end{array}$ & Tidak ada hambatan \\
\hline $\begin{array}{l}\text { c. Pengambilan } \\
\text { keputusan }\end{array}$ & $\begin{array}{l}\text { Hasil laporan tentang insiden } \\
\text { keselamatan pasien di rumah } \\
\text { sakit ini telah digunakan } \\
\text { sebagai dasar dalam } \\
\text { pengambilan keputusan } \\
\text { terutama untuk proses } \\
\text { pembelajaran dan peningkatan } \\
\text { mutu pelayanan }\end{array}$ & $\begin{array}{l}\text { Penggunaan hasil laporan } \\
\text { insiden keselamatan telah } \\
\text { sesuai dengan teori HMN } \\
\text { bahwa hasil digunakan untuk } \\
\text { pengambilan keputusan } \\
\text { terutama untuk sistem } \\
\text { perencanaan dan } \\
\text { pengembangan }\end{array}$ & Tidak ada hambatan \\
\hline
\end{tabular}

Kelengkapan data pada laporan insiden keselamatan pasien dapat dilihat dari aspek yang harus dilengkapi pada formulir laporan insiden keselamatan pasien rumah sakit ini. Pada formulir laporan insiden terdiri dari empat aspek. Aspek pertama yaitu data pasien yang terdiri dari nama, nomor rekam medis, ruangan, umur, penanggung biaya, jenis kelamin, dan tanggal masuk. Pada aspek kedua yaitu tentang rincian kejadian yang terdiri dari waktu insiden, kronologis insiden, jenis insiden, orang pertama yang melaporkan insiden, insiden terjadi kepada pasien atau lainnya, tempat insiden, unit kerja penyebab, akibat insiden, jenis tindakan yang dilakukan segera, dan pemberi tindakan. Pada aspek ketiga yaitu grading risiko. Sedangkan pada aspek keempat lembar investigasi sederhana untuk grading risiko biru atau hijau.

Berdasarkan hasil telaah dokumen formulir laporan insiden keselamatan pasien dan laporan insiden keselamatan pasien setiap triwulan. Kelengkapan data insiden keselamatan pasien rumah sakit ini sudah sesuai dengan ketentuan yang ada di panduan insiden keselamatan pasien rumah sakit. Kelengkapan data insiden keselamatan pasien sangat penting karena data tersebut akan digunakan untuk pengambilan keputuasan dan proses pembelajaran. Jika ada data yang tidak lengkap maka manajemen akan kesulitan untuk memperbaiki dan mencegah kesalahan yang sama.

Hasil dari laporan insiden keselamatan pasien digunakan sebagai bahan untuk pengambilan keputusan dan pembelajaran untuk individu maupun organisasi. Hasil laporan tentang insiden keselamatan pasien di rumah sakit ini telah digunakan sebagai dasar dalam pengambilan keputusan terutama untuk proses pembelajaran dan peningkatan mutu pelayanan. Berdasarkan wawancara dari informan, laporan digunakan oleh jajaran petinggi yayasan rumah sakit, jajaran direksi, dan manajer, dan komite PMKP. Informasi yang dihasilkan akan digunakan oleh berbagai tingkatan dalam sistem kesehatan di pelayanan kesehatan seperti pada sistem perencanaan dan pengembangan (WHO, 2008). Sistem informasi kesehatan merupakan komponen yang penting untuk koordinasi kesehatan dan untuk pengambilan keputusan yang baik (Ceken, 2014).

Salah satu pemanfaatan hasil laporan insiden keselamatan pasien untuk pengambilan keputusan 
adalah adanya kegiatan sosialisasi tentang keselamatan pasien yang dilakukan secara rutin tiap tahun sebagai upaya untuk meningkatkan pengetahuan karyawan tentang keselamatan pasien. Adanya perencanaan untuk mengikuti pelatihan keselamatan pasien yang diselenggarakan di luar rumah sakit bagi karyawan rumah sakit juga dapat ditentukan dari laporan ini. Hal tersebut dapat disimpulkan insiden keselamatan pasien telah dimanfaatkan oleh pengambil keputusan sebagai dasar pertimbangan perbaikan pelayanan Rumah sakit .

\section{SIMPULAN}

Rumah sakit ini telah memiliki sistem pelaporan insiden keselamatan pasien. Sistem pelaporan insiden keselamatan pasien tersebut sudah sesuai dengan Peraturan Menteri Kesehatan Nomor 11 Tahun 2017 tentang Keselamatan Pasien. Kebijakan dan panduan yang mengatur pelaporan tentang insiden keselamatan pasien pada pelaksanaannya masih belum sesuai dengan standar.

Rumah sakit ini diharapkan mampu memperbaiki kembali panduan terkait pelaporan insiden keselamatan pasien. Peningkatan kemampuan sumber daya manusia juga perlu direncanakan karena evaluasi pada semua aspek menunjukkan sistem yang gagal karena kelemahan sumber daya manusia. Peningkatan kualitas SDM ini juga harus diiringi dengan mengembangkan sistem komputerisasi untuk formulir laporan insiden keselamatan pasien.

\section{DAFTAR PUSTAKA}

Arfan, A. N., Pasinringi, S. A. . and Sidin, A. . I. (2013) Gambaran Determinan Insiden Keselamatan Pasien pada Petugas Kesehatan di Rumah Sakit Universitas Hasanuddin. Universitas Hasanuddin, Makasar. Available at: repository.unhas.ac.id.

Çeken, C. (2014) 'A Framework Study for Healthcare Information Systems', Journal of Computer and Communications, 2(September), pp. 6167.

doi: http://dx.doi.org/10.4236/jcc.2014.211008 A.

Doherty, C., Stavrapoulou, C. and Tosey, P. (2015) 'How Effective Are Incident-Reporting Systems for Improving Patient Safety? A Systematic Literature Review', The Milbank Quarterly, 93(4), pp. 826-866. doi: 10.1111/1468-0009.12166.

Elliott, P., Martin, D. and Neville, D. (2014) ‘Electronic clinical safety reporting system: A benefits evaluation', Journal of Medical Internet Research, 2(1), pp. 1-10. doi: 10.2196/medinform.3316.

Gunawan, Widodo, F. Y. and Harijanto, T. (2015) 'Analisis Rendahnya Laporan Insiden Keselamatan Pasien di Rumah Sakit', Jurnal Kedokteran Brawijaya, 28(2), pp. 206-213. Available at: jkb.ub.ac.id/index.php/jkb/article/download/9 62/479.
Hakim, L. and Pudjirahardjo, W. J. (2014) 'Optimalisasi Proses Koordinasi Program Keselamatan Pasien (Patient Safety) Di Rumah sakit Optimization of Coordinating Process of Patient Safety Program in Hospital X Surabaya', Jurnal Administrasi Kesehatan Indonesia, 2(3), pp. 198-208. Available at: journal.unair.ac.id/download-fullpapersjaki3404f1d0abfull.pdf.

Handayani, T. et al. (2013) 'Evaluasi pelaksanaan sistem pelaporan rekam medis di klinik asri medical center', Jurnal Manajemen Informasi Kesehatan Indonesia, 1(2), pp. 26-32. Available at: https://jmiki.aptirmik.or.id/index.php/jmiki/artic le/viewFile/47/33.

Indonesia, M. K. R. (2017) Peraturan menteri kesehatan Republik Indonesia Nomor 11 Tahun 2017 tentang Keselamatan Pasien, Peraturan Menteri Kesehatan Republik Indonesia Nomor 11 Tahun 2017 Tentang Keselamatan Pasien Dengan. Indonesia. Available at: jdih.baliprov.go.id/produkhukum/download/12274.

Jakti, U. B. (2016) Evaluasi Sistem Informasi Jejaring Rujukan Maternal-Neonatal (SIJARIEMAS) di Kabupaten Tegal dengan Pendekatan Model Health Metrics Network (HMN). Universitas Diponegoro. Available at: http://eprints.undip.ac.id/49454/.

Komite Keselamatan Pasien Rumah Sakit (2015) Pedoman Pelaporan Insiden Keselamatan Pasien (IKP), Komite Keselamatan Pasien Rumah Sakit. Jakarta. Available at: www.pdpersi.co.id.

Kurniavip, A. L. L. and Damayanti, N. A. (2017) 'Hubungan Karakteristik Individu Perawat dengan Insiden Keselamatan Pasien Tipe Administrasi Klinik di Rumah Sakit Umum Haji Surabaya', Jurnal Administrasi Kesehatan Indonesia, 5(2), pp. 117-122. doi: 10.20473/jaki.v5i2.2017.117-122.

Mbondji, P. E. et al. (2014) 'Health information systems in Africa: descriptive analysis of data sources, information products and health statistics', Journal of The Royal Society of Magazine, 107(15), pp. 34-45. doi: DOI: $10.1177 / 0141076814531750$.

Network, H. M. (2012) Framework and standards for country health information systems - second edition, World Health Organization. Switzerland. doi: 10.4018/978-1-60566-9885.

Nurmansyah, M. I. et al. (2015) 'Assessment of Nutrition Information System Using Health Metrics Network Framework', Jurnal Kesehatan Masyarakat Nasional Vol., 10(1), pp. 1-9. Available at: https://www.neliti.com/id/publications/147013 lassessment-of-nutrition-information-systemusing-health-metrics-network-framewor.

Pham, J. C., Girard, T. and Pronovost, P. J. (2013) 'What to do with healthcare Incident Reporting Systems', Journal of Public Health Research, 2(27), pp. 154-159. doi: 10.4081/jphr.2013.e27. 
Sanjaya, P. D., Rosa, E. M. and Ulfa, M. (2017) 'Evaluasi Penerapan Pencegahan Pasien Berisiko Jatuh di Rumah Sakit', Jurnal Fakultas Kesehatan Masyarakat, 11(2), pp. 105-113. Available

at: http://journal.uad.ac.id/index.php/KesMas/arti cle/download/6013/pdf 98.

Taylor, M. J. et al. (2014) 'Systematic review of the application of the plan-do-study-act method to improve quality in healthcare', BMJ Quality and Safety, 23, pp. 290-298. doi: 10.1136/bmjqs-2013-001862. 